\title{
Familial cytomegalic adrenocortical hypoplasia: an X-linked syndrome of pubertal failure
}

\author{
IAN D HAY, PETER J SMAIL, AND CONSTANCE C FORSYTH \\ University Department of Medicine, Royal Infirmary, Glasgow, and University Department of Child Health, \\ Ninewells Hospital, Dundee
}

SUMMARY Five boys with familial cytomegalic adrenocortical hypoplasia have been followed up for an average of 19 years. Despite treatment with replacement corticosteroids, all 5 failed to show a spontaneous onset of puberty and, when assessed at ages 13 to 19 years, all had both sexual infantilism and skeletal immaturity. Hypogonadism was confirmed by low levels of plasma testosterone, and pituitary reserve of gonadotrophin was shown to be inadequate by testing with gonadotrophinreleasing hormone. Two boys, both with adequate testosterone output on human chorionic gonadotrophin stimulation, were given gonadotrophin therapy, whereas the other 3 were treated with parenterally administered testosterone. With treatment, all 5 patients showed advances in pubertal staging. Although the mechanism of the hypogonadotrophism remains unclear, the association of hypogonadotrophic hypogonadism with familial cytomegalic adrenocortical hypoplasia appears to be a constant one and may be considered as a treatable inherited syndrome of pubertal failure.

The primary or cytomegalic type of congenital adrenal hypoplasia is characterised pathologically by adrenal cortices without zonal differentiation and the presence therein of irregularly-placed, large vacuolated cells resembling those seen in the normal fetal adrenal gland. ${ }^{1}$ The condition was first recognised by $\mathrm{Sikl}^{2}$ in 1948, and a family with 2 affected brothers was first described in 1959 by Mitchell and Rhaney. ${ }^{3}$ In 1968, the X-linked inheritance of the condition was demonstrated, ${ }^{4}$ and by 1975 , Mamelle et al. ${ }^{5}$ had identified 20 cases proved at necropsy and had described 6 surviving boys assumed to have familial cytomegalic adrenocortical hypoplasia (FCAH).

In 1975, Prader et al. ${ }^{6}$ described a boy with congenital adrenal hypoplasia who failed to show signs of puberty by age 16 years and at age 18 years was found to have hypogonadotrophic hypogonadism. During 1977, 3 more cases of this association were reported, ${ }^{7-9}$ and one of us (IDH) presented preliminary evidence ${ }^{10}$ that the 5 oldest surviving patients with $\mathrm{FCAH}^{5}$ also shared this problem. We present further clinical and biological details of these 5 patients, none of whom, by age 20 years, had spontaneously entered puberty.

\section{Materials and methods}

All 5 of our patients have been described previously. Details of their long-term progress were obtained by contact with the authors of the initial reports. Although none of the 5 patients was still being attended by the original authors, through their co-operation, the current status of each patient was ascertained.

\section{Case reports}

Case 1. Details of this patient's birth, initial diagnosis, and progress to age 5 years were reported by Mitchell and Rhaney. ${ }^{311}$ From 5 to 7 years he progressed satisfactorily on treatment of $15 \mathrm{mg}$ cortisone and $0.2 \mathrm{mg}$ fludrocortisone daily. His height continued to be at the 75th centile, and his height velocity approximated the 50th centile. His bone age determined in January 1965 (chronological age 6.9 years) was 6.2 years. At age 10.7 years his height was still at the 50th centile, his pubertal rating was stage 1 , and his bone age was estimated at 8.6 years.

He had recurrent left-sided convulsions when aged 13, and an electroencephalogram (EEG) showed a paroxysmal abnormality with a right temporoparietal focus. His focal seizures were controlled by treatment with phenytoin. At age 14 years his height was at the 25th centile, and an estimation of urinary 11-deoxy-17-oxosteroids showed a lack of the normal increase in adrenal androgens. ${ }^{12}$ By age 14.9 years his bone age was 3 years delayed, height had 
decreased to below the 25th centile, and urinary androgens were at the limit of detection. Clinical examination showed no signs of puberty.

At age 17 the glucocorticoid replacement was changed to hydrocortisone, $20 \mathrm{mg}$ in the morning and $10 \mathrm{mg}$ in the afternoon, but fludrocortisone therapy was continued at $0.2 \mathrm{mg}$ daily. His height was at the 10th centile, and physical examination showed cutaneous pigmentation and a pubertal rating of stage 1 . His bone age was 4 years retarded, and his height velocity chart showed no evidence of a pubertal growth spurt, his whole-year increments having decreased progressively since the 12 th year of life. The plasma testosterone (T) level at this time was less than $5 \mathrm{ng} / 100 \mathrm{ml}(<0 \cdot 2 \mathrm{nmol} / \mathrm{l})$, and the serum luteinising hormone (LH) and folliclestimulating hormone (FSH) levels were $0 \cdot 2$ and $<1.0 \mathrm{U} / \mathrm{l}$ respectively. Pituitary gonadotrophin reserve was assessed by a stimulation test, with use of intravenous gonadotrophin-releasing hormone $(\mathrm{GnRH})$, and was found to be greatly diminished (Table 1).

At age $18 \cdot 2$ years the patient was less pigmented but remained prepubertal, his plasma $T$ level still remaining undetectable. The GnRH test was repeated (Table 1), and subsequently $5000 \mathrm{IU}$ of human chorionic gonadotrophin (hCG) was administered daily for 4 days to assess Leydig cell function. On the fourth day after administration of hCG, the plasma $T$ level remained low at $14 \mathrm{ng} / 100$ $\mathrm{ml}(0.5 \mathrm{nmol} / \mathrm{l})$. When reassessed at age $19 \cdot 2$ years, the patient had a bone age of 13.5 years, a plasma $\mathrm{T}$ level of $7 \mathrm{ng} / 100 \mathrm{ml}(0 \cdot 2 \mathrm{nmol} / \mathrm{l})$, and a gonadotrophin reserve that was essentially unchanged (Table 1). A repeat hCG stimulation test $(5000$ $\mathrm{IU} \times 4$ ) showed an increase in plasma $\mathrm{T}$ from 10 to $60 \mathrm{ng} / 100 \mathrm{ml}(0 \cdot 3$ to $2 \cdot 1 \mathrm{nmol} / \mathrm{l})$.

At age $20 \cdot 2$ years he continued to be mildly pigmented and prepubertal (Tanner stage 1 with testicular volumes of $2 \mathrm{ml}$ on the right and $3 \mathrm{ml}$ on the left). The plasma $\mathrm{T}$ level was still low at $30 \mathrm{ng} / 100$ $\mathrm{ml}(1 \cdot 1 \mathrm{nmol} / \mathrm{l})$, and the serum LH and FSH levels were less than 0.5 and $1.4 \mathrm{U} / 1$ respectively. Androgen replacement was started with mesterolone, $25 \mathrm{mg}$ three times a day, but this regimen was later replaced by intramuscular injections of $250 \mathrm{mg}$ testosterone esters every 2 weeks. Two months after this treatment was begun, the patient was observed to have advanced to between stages 2 and 3 of puberty, and 7 months later he had advanced to stage 4 of puberty, with testicular volumes of $4 \mathrm{ml}$ and a bone age of $15 \cdot 3$ years.

Case 2. This patient was originally reported as case 1 by Uttley ${ }^{13}$ and was described subsequently. ${ }^{10}$ Born in November 1959, he was the product of a normal pregnancy and labour. The family history (Fig. 1) was relevant, in that 2 of the mother's 9 sons had died 'within minutes' at home and 1 (case 2 of Uttley ${ }^{13}$ ) had died at 11 days because of cytomegalic hypoplasia. The remaining 5 boys were both clinically and biochemically normal.

FCAH was diagnosed at age 5.4 years and he was treated with cortisone, $12 \cdot 5 \mathrm{mg}$ twice a day, and fludrocortisone, $0.05 \mathrm{mg}$ daily.

Between ages 6 and 11 his growth paralleled the standard growth curves, and at age 10.7 years on a daily treatment programme of $25 \mathrm{mg}$ cortisone and $0.05 \mathrm{mg}$ fludrocortisone, he weighed $25.5 \mathrm{~kg}$ and was $132 \cdot 5 \mathrm{~cm}$ tall (10th centile).

When $14 \cdot 1$ years old he was admitted to hospital because of short stature and delayed pubertal development. Examination showed no abnormal pigmentation, a height of $142.0 \mathrm{~cm}$ (3rd centile), and a pubertal staging of 1 . The patient was thought to have idiopathic delayed puberty that would probably respond to treatment with hCG. Accordingly, a programme of $100 \mathrm{IU}$ of hCG weekly for 6 injections

Table 1 Basal plasma testosterone and serum luteinising hormone and follicle-stimulating hormone concentrations in response to intravenous bolus doses of gonadotrophin-releasing hormone in 3 cases of familial cytomegalic adrenocortical hypoplasia

\begin{tabular}{|c|c|c|c|c|c|c|c|c|c|c|}
\hline \multirow[t]{2}{*}{ Case } & \multirow{2}{*}{$\begin{array}{l}\text { Chronological } \\
\text { age (years) }\end{array}$} & \multirow{2}{*}{$\begin{array}{l}\text { Plasma T } \\
(n g / 100 \mathrm{ml})\end{array}$} & \multicolumn{4}{|c|}{ Serum $L H(U / l)$} & \multicolumn{4}{|c|}{ Serum FSH $(U / l)$} \\
\hline & & & 0 & 30 & 60 & Increment & 0 & 30 & 60 & Increment \\
\hline 1 & $\begin{array}{l}17 \cdot 5 \\
18 \cdot 2 \\
19 \cdot 2\end{array}$ & $\begin{array}{r}<5 \\
<12 \\
7\end{array}$ & $\begin{array}{r}<1.0 \\
3.0 \\
<1.0\end{array}$ & $\begin{array}{r}4 \cdot 1 \\
5 \cdot 3 \\
<1 \cdot 0\end{array}$ & $\begin{array}{r}4 \cdot 1 \\
6 \cdot 1 \\
<1 \cdot 0\end{array}$ & $\begin{array}{l}3 \cdot 1 \\
3 \cdot 1 \\
0\end{array}$ & $\begin{array}{l}0 \cdot 2 \\
1 \cdot 3 \\
1 \cdot 1\end{array}$ & $\begin{array}{l}0.4 \\
1 \cdot 7 \\
1.6\end{array}$ & $\begin{array}{l}0 \cdot 5 \\
1 \cdot 8 \\
1 \cdot 8\end{array}$ & $\begin{array}{l}0.3 \\
0 \cdot 5 \\
0 \cdot 7\end{array}$ \\
\hline 2 & $\begin{array}{l}16 \cdot 5 \\
16 \cdot 7^{*} \\
17 \cdot 5\end{array}$ & $\begin{array}{r}6 \\
14 \\
26\end{array}$ & $\begin{array}{r}<4.1 \\
<3.2 \\
0.9\end{array}$ & $\begin{array}{r}<4 \cdot 1 \\
<3 \cdot 2 \\
2 \cdot 1\end{array}$ & $\begin{array}{r}<4 \cdot 1 \\
<3 \cdot 2 \\
1 \cdot 5\end{array}$ & $\begin{array}{l}0 \\
0 \\
1 \cdot 2\end{array}$ & $\begin{array}{r}<0.9 \\
<1.2 \\
0.9\end{array}$ & $\begin{array}{r}<0.9 \\
<1.2 \\
1.4\end{array}$ & $\begin{array}{r}<0.9 \\
<1.2 \\
0.9\end{array}$ & $\begin{array}{l}0 \\
0 \\
0 \cdot 5\end{array}$ \\
\hline
\end{tabular}

* $250 \mu \mathrm{g}$ dose was used; in all others $100 \mu \mathrm{g}$ bolus was used.

Conversion: traditional to SI units testosterone: $1 \mathrm{ng} / 100 \mathrm{ml} \approx 0.035 \mathrm{nmol} / 1$. 
was started. Eight months later the patient had completed this treatment, and because of persistent hyponatraemia and hyperkalaemia, the fludrocortisone dose was increased to $0 \cdot 1 \mathrm{mg}$ daily.

When reassessed at age $15 \cdot 3$ years he was below the 3 rd centile in height, still at pubertal stage 1 , and had a 4-year retarded bone age. Hypothyroidism and growth hormone deficiency were excluded by euthyroid basal serum levels of T4 and T3, a normal response of thyroid-stimulating hormone to thyrotrophin-releasing hormone, and an adequate response of growth hormone in a prolonged glucose tolerance test. When he was 16 years old, treatment with $3000 \mathrm{IU}$ of hCG twice weekly was recommended. Six months later, 4 weeks after the course of hCG treatment had been completed, the patient returned for evaluation; he had grown $10 \mathrm{~cm}$ in height over a period of 15 months. His pubertal rating was now stage 2 , his bone age was less immature, but plasma $T$ remained low at $6 \mathrm{ng} / 100 \mathrm{ml}(0.2 \mathrm{nmol} / \mathrm{l})$. A GnRH test was performed and the results (Table 1) showed a lack of response. The test was repeated with a larger $250 \mu \mathrm{g}$ bolus; despite this increased stimulus there was no response of $\mathrm{LH}$ or FSH. Hypogonadotrophic hypogonadism was diagnosed.

At age $17 \cdot 5$ years the patient was again evaluated. Endocrine testing showed continuing gonadotrophin deficiency (Table 1) in an otherwise hormonally intact anterior pituitary. Leydig cell function, as shown by $T$ output in response to hCG stimulation, was normal. The patient was offered the choice of either continuing hCG or starting androgen therapy, but he declined both. When seen for review at 17.9 years, his height was $162 \mathrm{~cm}$ (3rd centile) and his pubertal rating stage 2 . Basal plasma $T$ level was $35 \mathrm{ng} / 100 \mathrm{ml}(1 \cdot 2 \mathrm{nmol} / \mathrm{l})$, with a serum LH level of 0.9 and a serum FSH level of $0.8 \mathrm{U} / 1$.

Case 3. This patient's progress to age 7 years was described by Uttley ${ }^{13}$ as his case 3. Further details were given in an abstract by Harkness and Thistlethwaite. ${ }^{14}$ From age 10 to 14 years, the patient enjoyed good health on a replacement regimen of cortisone (10 mg twice a day) and added salt (4 g/day); consequently, his parents reduced his cortisone dose from 20 to $5 \mathrm{mg}$ daily. At age 14.7 years he asked to be examined because of lack of pubertal changes. Evaluation showed that he was $168 \mathrm{~cm}$ tall and above the mean weight for his age. $\mathrm{He}$ was diffusely pigmented and had good muscular development, but his testes were infantile and pubic hair had not developed.

Urinary 17-hydroxycorticosteroid excretion was $0.4 \mathrm{mg} / 24 \mathrm{~h}(1.4 \mu \mathrm{mol} / 24 \mathrm{~h})$, and plasma cortisol, at both 2300 and 0900 hours, was $0.9 \mu \mathrm{g} / 100 \mathrm{ml}$ $(25 \mathrm{nmol} / \mathrm{l})$. The level of plasma ACTH before administration of the morning cortisone dose was $1462 \mathrm{pg} / \mathrm{ml}(321.6 \mathrm{pmol} / \mathrm{l})$. Basal plasma $\mathrm{T}$ level was low at $87 \mathrm{ng} / 100 \mathrm{ml}(3.0 \mathrm{nmol} / \mathrm{l})$. A GnRH test was therefore performed and showed greatly decreased responses of LH and FSH (Table 1). An hCG stimulation test was also carried out; after 2 days, the plasma $\mathrm{T}$ level increased to $253 \mathrm{ng} / 100 \mathrm{ml}(8.9$ $\mathrm{nmol} / \mathrm{l}$ ), an indication of normal Leydig cell function. Glucocorticoid replacement was increased to $35 \mathrm{mg}$ of cortisone daily in divided doses, but mineralocorticoid replacement was maintained at $0.1 \mathrm{mg}$ daily.

At age 15.4 years he showed some evidence of pubertal development. The testes were said to be $4 \mathrm{ml}$ in size, and the penis had enlarged. Plasma T level was $129 \mathrm{ng} / 100 \mathrm{ml}(4.5 \mathrm{nmol} / \mathrm{l})$, and a GnRH test (Table 1) showed a significant response of serum LH. Eight months later he had a generalised convulsion during a slight upper respiratory tract infection. There was no clinical evidence of hypoglycaemia, but an EEG showed clear evidence of an epileptic phenomenon. Treatment with phenobarbitone, $60 \mathrm{mg}$ three times a day, was therefore begun.

His pubertal development continued, and when he was $16 \cdot 2$ years old he had stage 3 genitalia and stage 2 pubic hair. His bone age was only slightly delayed at 15.4 years. Plasma $T$ level remained at 128 $\mathrm{ng} / 100 \mathrm{ml}(4.5 \mathrm{nmol} / \mathrm{l})$, and basal serum levels of LH and FSH were 3.5 and $3.3 \mathrm{U} / 1$ respectively.

At age 17.0 years he presented complaining of pubertal delay. At that time, his voice had not broken and he was not having erections. Examination showed that he was taller than average and had slight pigmentation but no facial or axillary hair. His pubic hair was scanty, and he had a small penis, with testes measuring $3 \times 1.5 \mathrm{~cm}$. Plasma $T$ level was $61 \mathrm{ng} / 100 \mathrm{ml}(2 \cdot 1 \mathrm{nmol} / \mathrm{l})$, and the GnRH test (Table 1) showed a small LH increment, with almost no response in FSH. A standard 4-day hCG stimulation test confirmed adequate Leydig cell reserve, and in June 1978 the decision was made to institute regular hCG treatment.

Immediately before treatment was started, the patient, then 17.9 years old and $178 \mathrm{~cm}$ tall $(75$ th centile), had testicular volumes of $2 \mathrm{ml}$ bilaterally and a basal plasma $T$ level of $23 \mathrm{ng} / 100 \mathrm{ml}(0.8$ $\mathrm{nmol} / \mathrm{l})$. A dose of 1500 units of hCG was administered twice weekly; after 7 months of treatment, his plasma $\mathrm{T}$ level had increased to $500 \mathrm{ng} / 100 \mathrm{ml}$ $(17 \cdot 5 \mathrm{nmol} / \mathrm{l})$, pubic hair was stage 3 , and testicular volumes had increased to $4 \mathrm{ml}$ on the right and $5 \mathrm{ml}$ on the left. 
Case 4. This patient, born in 1961, was first described as case 1 of Bickham et al..$^{15}$ and subsequently as case II $\cdot 2$ in the pedigree of Weiss and Mellinger. ${ }^{16}$ From age 7 to 15 years he enjoyed good health, and his height and weight stayed within 1 standard deviation of the expected mean. During this time he had problems with multiple allergies and received regular courses of desensitising injections.

At age $16 \cdot 2$ years he was re-examined for investigation of his pubertal status. At that time his daily treatment was $25 \mathrm{mg}$ hydrocortisone and $0.1 \mathrm{mg}$ fludrocortisone, and his height and weight were $161 \mathrm{~cm}$ and $50 \mathrm{~kg}$. On examination, he had slight facial pigmentation, no facial, axillary, or pubic hair, and stage 1 genital development. The basal plasma $\mathrm{T}$ level was $51 \mathrm{ng} / 100 \mathrm{ml}(1 \cdot 8 \mathrm{nmol} / \mathrm{l})$, and his bone age was retarded at 13.5 years. A GnRH test was performed, $100 \mu \mathrm{g}$ being infused during a 3-hour period. No significant response was obtained (Table 2), and hypogonadotrophic hypogonadism was diagnosed.

Androgen replacement in the form of testosterone cypionate, $100 \mathrm{mg}$ monthly, was started at age 16.7 years. When seen for review after one year of treatment, he had grown $12.5 \mathrm{~cm}$ in height, had slight hair growth on the upper lip, and had stage 4 pubic hair and genital development. Axillary hair continued to be absent, and the testes remained infantile in size.

Case 5. This patient, the half-brother of Case 4 (Fig. 1), was first described by Bickham et al. ${ }^{15}$ and later by Weiss and Mellinger. ${ }^{16}$ Born in 1964, he
Table 2 Plasma testosterone, serum luteinising hormone, and follicle-stimulating hormone concentrations in response to a 3-hour intravenous infusion of $100 \mu \mathrm{g}$ of GnRH in Cases 4 and 5

\begin{tabular}{|c|c|c|c|c|}
\hline & $O \min$ & $60 \mathrm{~min}$ & $120 \mathrm{~min}$ & $180 \mathrm{~min}$ \\
\hline \multicolumn{5}{|l|}{ Case 4} \\
\hline Luteinising hormone (U/I) & $3 \cdot 8$ & $1 \cdot 9$ & $2 \cdot 6$ & $3 \cdot 2$ \\
\hline $\begin{array}{l}\text { Follicle-stimulating hormone } \\
\text { (U/1) }\end{array}$ & $2 \cdot 1$ & $2 \cdot 5$ & $1 \cdot 6$ & $1 \cdot \overline{8}$ \\
\hline Testosterone $(\mathrm{ng} / 100 \mathrm{ml})$ & 51 & 49 & 45 & 57 \\
\hline \multicolumn{5}{|l|}{ Case 5} \\
\hline Luteinising hormone (U/1) & 1.9 & $3 \cdot 2$ & $1 \cdot 5$ & $2 \cdot 6$ \\
\hline (U/1) & 0.4 & 0.5 & $2 \cdot 6$ & 1.4 \\
\hline
\end{tabular}

ND $=$ not detectable.

progressed well between 1965 and 1977. Although during this time his doses of both glucocorticoid and mineralocorticoid varied, his growth pattern remained normal (Fig. 2).

When seen for review at age $12 \cdot 6$ years he was $151 \mathrm{~cm}$ tall (50th centile), and his bone age was retarded at 10 years. On examination he had no signs of adrenal insufficiency, but like his older halfbrother, he had no pubic hair and his genital development was at stage 1 (preadolescent). A plasma $T$ level was below the limit of detection $(<15$ $\mathrm{ng} / 100 \mathrm{ml} ;<0.5 \mathrm{nmol} / \mathrm{l})$, and a GnRH infusion (Table 2) confirmed the diagnosis of FCÄH with associated hypogonadotrophic hypogonadism.

The patient (like his half-brother) started androgen replacement with testosterone cypionate $(100 \mathrm{mg}$

\section{Family 1}

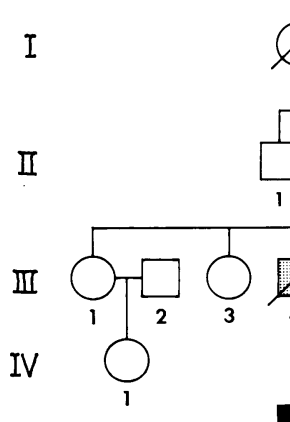

Family 2

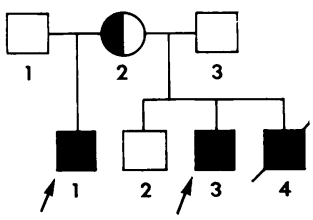

${ }_{1} \underbrace{}_{3} \underbrace{}_{4} \bigcup_{5} \underbrace{}_{7}$
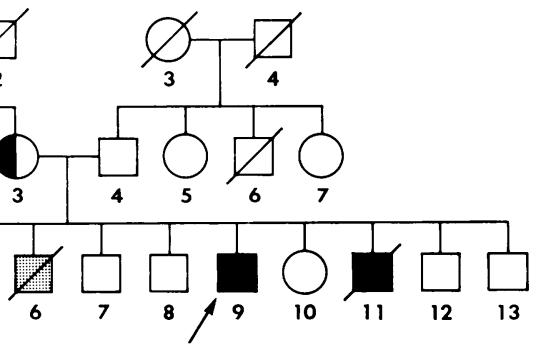

Familial cytomegalic adrenocortical hypoplasia (FCAH)

Probable FCAH Dresumed carrier

Fig. 1 Pedigrees of two families with familial cytomegalic adrenocortical hypoplasia. Case 2 is III-9 in family 1. Cases 4 and 5 are II-1 and II-3 in family 2. In both III-1I (family I) and II-4 (family 2), necropsy showed the histological signs of cytomegalic adrenocortical hypoplasia. 


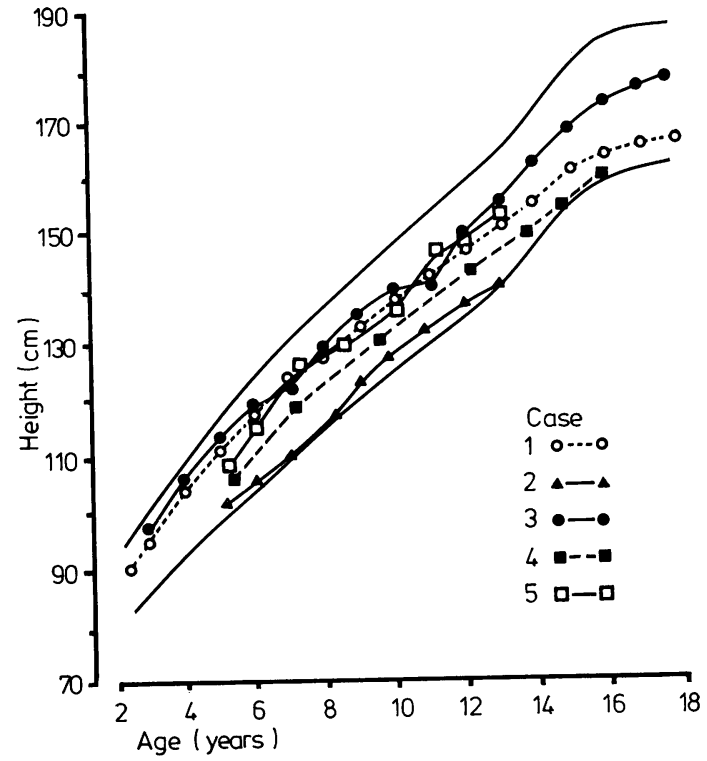

Fig. 2 Growth curves of 5 boys with familial cytomegalic adrenocortical hypoplasia and associated hypogonadotrophic hypogonadism. These curves represent growth before the start of treatment with either testosterone or gonadotrophin. Unbroken lines represent the 97th and 3rd centiles.

monthly) at age 13.2 years. When seen after one year of treatment, he had gained $18 \mathrm{~cm}$ in height, had developed slight facial acne, and had a moderate growth of pubic hair. Penile development had advanced to stage 3 , but no axillary hair was present, and the testes remained infantile.

\section{Discussion}

When Prader et al. ${ }^{6}$ in 1975, reported their case of hypogonadotrophic hypogonadism associated with congenital adrenal hypoplasia, they questioned ... whether gonadotropin deficiency is a regular or exceptional manifestation in this condition.' Since their original description, 5 more patients have been described ${ }^{7-9} 1718$ all of whom, at chronological ages of between $13 \cdot 5$ and 21 years, had impaired skeletal maturation despite normal heights. Although all were boys, suggesting an X-linked cytomegaly as the underlying pathological condition, none of the patients or their affected relatives had microscopical examination of the adrenal glands to determine the histological type of adrenocortical change.

By contrast, in the present study, we identified the 9 surviving patients with pathologically verified
FCAH and have reported on the progress during an average period of 19 years (range 15 to 21 ) of the 5 oldest patients with this rare condition. Growth curves of untreated patients with hypogonadotrophic hypogonadism were initially described in $1977,{ }^{19}$ and in the present report, we define for the first time the preadolescent and adolescent growth patterns of patients with the hypogonadotrophic hypogonadism associated with FCAH (Fig. 2). Moreover, we describe the successful treatment in all 5 patients of the pubertal failure that is seen as a universal accompaniment of this syndrome.

Although cytomegalic adrenocortical hypoplasia was first reported more than 30 years ago, ${ }^{2}$ its cause remains unknown. In 1957, Harlem and Myhre ${ }^{20}$ suggested 'an organogenetic injury' of the adrenal glands in early fetal life, and later workers ${ }^{16}$ implicated the failure of an 'inducer substance' normally responsible for the formation of adult cortex. Possibilities for this inducer substance have included $\mathrm{ACTH},{ }^{21} \alpha$-melanocyte-stimulating hormone, ${ }^{22}$ corticotrophin-like intermediate lobe peptide, ${ }^{22}$ prolactin, ${ }^{23}$ and a corticotrophin-like placental hormone known as human chorionic corticotrophin. ${ }^{24}$ So far there is no agreement about the identity of the inducer substance. Indeed, one piece of evidence that argues against a humoral factor deficiency is the finding, in one patient with cytomegalic adrenocortical hypoplasia, ${ }^{25}$ of bilateral hypoplastic adrenal glands with no permanent cortex and an accessory adrenal gland within one epididymis that showed the normal zonation of a permanent adult cortex.

Further uncertainty also surrounds the identity of a factor believed to be responsible for the progressive increase in adrenal androgen output seen in children with normal adrenal function and occurring about 2 years before the pubertal increase in gonadotrophin and gonadal sex steroid secretion. ${ }^{26}$ Possibilities have included hypothalamic releasing factors, pituitary hormones other than ACTH, unknown pituitary hormones, and steroids such as oestrogen. ${ }^{27}$ Recent opinion has favoured an as yet unidentified pituitary hormone acting synergistically with ACTH and called adrenal androgen-stimulating hormone ${ }^{26} 28$ or cortical androgen-stimulating hormone. ${ }^{29}$

When FCAH was first described by Mitchell and Rhaney $^{3}$ about 20 years ago, the adrenal hypoplasia was assumed to be a singular genetic error. These same authors, ${ }^{11}$ however, in 1963, expressed the hope '. . . that no other hormonal deficiency will become apparent at puberty.'

In this study, we provided evidence that patients with FCAH, although appearing to grow normally, do not have a pubertal growth spurt or the spontaneous development of the skeletal and sexual 
maturity associated with normal puberty. If an important role exists for the 'adrenarche' in the maturation of the hypothalamic-pituitary gonadal axis, ${ }^{30}$ one might have predicted a delay in the occurrence of puberty in patients who, like our Case 1, showed no evidence of adrenal androgen production. If however, the pubertal maturation of the adrenal cortex and that of the hypothalamicpituitary-gonadal axis are independent, ${ }^{31}$ one would not expect a delay in pubertal development.

Only 2 cases of congenital adrenal hypoplasia have been reported in which GnRH tests were repeated after up to a week of continuous GnRH stimulation. In both of these, ${ }^{917}$ the second test dose produced minimally improved responses, and the results in the second case $^{17}$ were considered as evidence that GnRH deficiency was the underlying cause of the clinical hypogonadism. We believe that these results will have to be verified and that this form of investigation should be one of the first aspects to be examined closely in future studies of this interesting and unusual $\mathrm{X}$-linked syndrome of pubertal failure.

We thank the following for help with the clinical and biochemical evaluation of these cases: $\operatorname{Dr} R \mathbf{C}$ Mellinger, Detroit, Michigan, USA (Cases 4 and 5); Dr W S Uttley, Dr D Thistlethwaite, Dr R A Harkness, Dr G W Stewart, Dr N C Fraser, Professor J A Strong and Professor J W Farquhar, Edinburgh (Case 3); Dr G H Beastall, Dr J K Grant, Dr W A Ratcliffe, and Dr J A Thomson, Glasgow (Case 2).

\section{References}

1 Kerenyi N. Congenital adrenal hypoplasia: report of a case with extreme adrenal hypoplasia and neurohypophyseal aplasia, drawing attention to certain aspects of etiology and classification. Arch Pathol 1961; 71: 336-43.

2 Šikl H. Addison's disease due to congenital hypoplasia of the adrenals in an infant aged 33 days. $J$ Pathol Bacteriol 1948; 60: 323-4.

${ }^{3}$ Mitchell R G, Rhaney K. Congenital adrenal hypoplasia in siblings. Lancet 1959; i: 488-92.

4 Dacou C, Di George A M. Evidence for an X-linked form of congenital adrenal hypoplasia (abstract). Program of the Thirty-eighth Annual Meeting of the Society for Pediatric Research, Atlantic City, New Jersey, 1968: 89.

5 Mamelle J-C, David M, Riou D, et al. Hypoplasie surrénalienne congénitale de type cytomégalique forme recéssive liée au sexe: à propos de trois observations. Arch Fr Pediatr 1975; 32: 139-59.

${ }^{6}$ Prader A, Zachmann M, Illig R. Luteinizing hormone deficiency in hereditary congenital adrenal hypoplasia. J Pediatr 1975; 86: 421-2.
7 Kelly W F, Joplin G F, Pearson G W. Gonadotrophin deficiency and adrenocortical insufficiency in children: a new syndrome. $\mathrm{Br}$ Med J 1977; ii: 98.

8 Golden M P, Lippe B M, Kaplan S A. Congenital adrenal hypoplasia and hypogonadotropic hypogonadism. $A m \mathrm{~J}$ Dis Child 1977; 131 : 1117-8.

9 Black S, Brook C G D, Cox P J N. Congenital adrenal hypoplasia and gonadotrophin deficiency. Br Med J 1977; ii: 996.

10 Hay I D. Letter: Pubertal failure in congenital adrenocortical hypoplasia. Lancet 1977 ; ii: 1035-6.

11 Mitchell R G, Rhaney K. Letter: Congenital adrenal hypoplasia. Lancet 1963; ii: 1065-6.

12 Savage D C L, Forsyth C C, McCafferty E, Cameron J. The excretion of individual adrenocortical steroids during normal childhood and adolescence. Acta Endocrinol (Kbh) 1975; 79: 551-67.

13 Uttley W S. Familial congenital adrenal hypoplasia. Arch Dis Child 1968; 43: 724-30.

14 Harkness R A, Thistlethwaite D. Delayed puberty in adrenocortical hypoplasia (abstract). Pediatr Res 1978; 12: 156 .

15 Bickham R E, Silvestre D, Mellinger R C. Addison's disease in half-siblings. Henry Ford Hosp Med J 1968; 16: $157-62$.

16 Weiss L, Mellinger R C. Congenital adrenal hypoplasiaan X-linked disease. J Med Genet 1970; 7: 27-32.

17 Richards G E, Conte F A, Kaplan S L, Grumbach M M. Congenital adrenal hypoplasia and isolated gonadotropin deficiency: ability of gonadotropes to respond to LRF (abstract). Clin Res 1978; 26: 171A.

18 Edwards O M, Dent R G. Congenital adrenal hypoplasia and delayed puberty (abstract). Case presented to Royal Society of Medicine, Cambridge, 24 May 1978.

19 Copeland K C, Paunier L, Sizonenko P C. The secretion of adrenal androgens and growth patterns of patients with hypogonadotropic hypogonadism and idiopathic delayed puberty. J Pediatr 1977; 91 : 985-90.

20 Harlem O K, Myhre E. Congenital adrenal hypoplasia: report of a case with the characteristic clinical features of dysadrenocorticism and autopsy findings of extreme hypoplasia of the adrenal glands. Am J Dis Child 1957; 94: 696-701.

21 Sperling M A, Wolfsen A R, Fisher D A. Congenital adrenal hypoplasia: an isolated defect of organogenesis. J Pediatr 1973; 82: 444-9.

22 Rees L H. ACTH, lipotrophin, and MSH in health and disease. Clin Endocrinol Metab 1977; 6: 137-53.

23 Genazzani A R, Pintor C, Facchinetti F, Carboni G, Pelosi U, Corda R. Adrenal and gonadal steroids in girls during sexual maturation. Clin Endocrinol (Oxf) 1978; 8: $15-25$.

24 Genazzani A R, Fraioli F, Hurlimann J, Fioretti P, Felber J P. Immunoreactive ACTH and cortisol plasma levels during pregnancy: detection and partial purification of corticotrophin-like placental hormone; the human chorionic corticotrophin (hCC). Clin Endocrinol (Oxf) $1975 ; 4: 1-14$.

25 Zondek L H, Zondek T. Congenital adrenal hypoplasia in two infants. Acta Paediatr Scand 1968; $57: 250-4$.

26 Grumbach M M, Richards G E, Conte F A, Kaplan S L. Clinical disorders of adrenal function and puberty: an assessment of the role of the adrenal cortex in normal and abnormal puberty in man, and evidence for an ACTH-like pituitary adrenal androgen stimulating hormone. In: James V H T, Serio M, Giusti G, Martini L, eds. The endocrine function of the human adrenal cortex. London: Academic Press, 1978 : 583-612. 
27 Parker L N, Chang S, Odell W D. Adrenal androgens in patients with chronic marked elevation of prolactin. Clin Endocrinol $(O x f) 1978 ; 8$ : 1-5.

28 Visser H K A. Some physiological and clinical aspects of puberty. Arch Dis Child 1973; 48: 169-82.

29 Parker L, Odell W. Control of adrenal androgen secretion by a new pituitary factor: cortical androgen stimulating hormone (CASH) (abstract). Clin Res 1977; 25: 299A.

30 Forest M G, De Peretti E, Bertrand J. Hypothalamicpituitary-gonadal relationships in man from birth to puberty. Clin Endocrinol $(O x f) 1976$; 5: 551-69.
31 Sizonenko P C. Preadolescent and adolescent endocrinology: physiology and physiopathology. II. Hormonal changes during abnormal pubertal development. Am J Dis Child 1978; 132: 797-805.

Correspondence to Dr I D Hay, University Department of Medicine, Western General Hospital, Crewe Road, Edinburgh EH4 2XU.

Received 25 June 1980

\section{The following articles will appear in future issues of this journal:}

Child growth (0-5 years), and the effect of entitlement to a milk supplement

$P C$ Elwood, $T J L$ Haley, $S J$ Hughes, $P$ M Sweetnam, $O P$ Gray, and D P Davies

Acute splenic sequestration and hypersplenism in the first five years in homozygous sickle cell disease $J M$ Topley, $D W$ Rogers, $M C G$ Stevens, and $G R$ Serjeant

Validity of routine clinical test weighing as a measure of the intake of breast-fed infants $M F$ Whitfield, $R$ Kay, and S Stevens

Fifth day fits: a syndrome of neonatal convulsions $D S$ Pryor, $N$ Don, and D C Macourt

Hyperphenylalaninaemia of various types among three-quarters of a million neonates tested in a screening programme

$V$ Walker, B E Clayton, $R$ S Ersser, D E M Francis, P Lilly, $J W T$ Seakins, I Smith, and P $D$ Whiteman

Mitochondrial cytopathy. A multisystem disorder with ragged red fibres on muscle biopsy

$J$ Egger, $B$ D Lake, and $J$ Wilson

Prolactin, maternal oestrogens, and breast development in the newborn

J F McKiernan and D Hull 